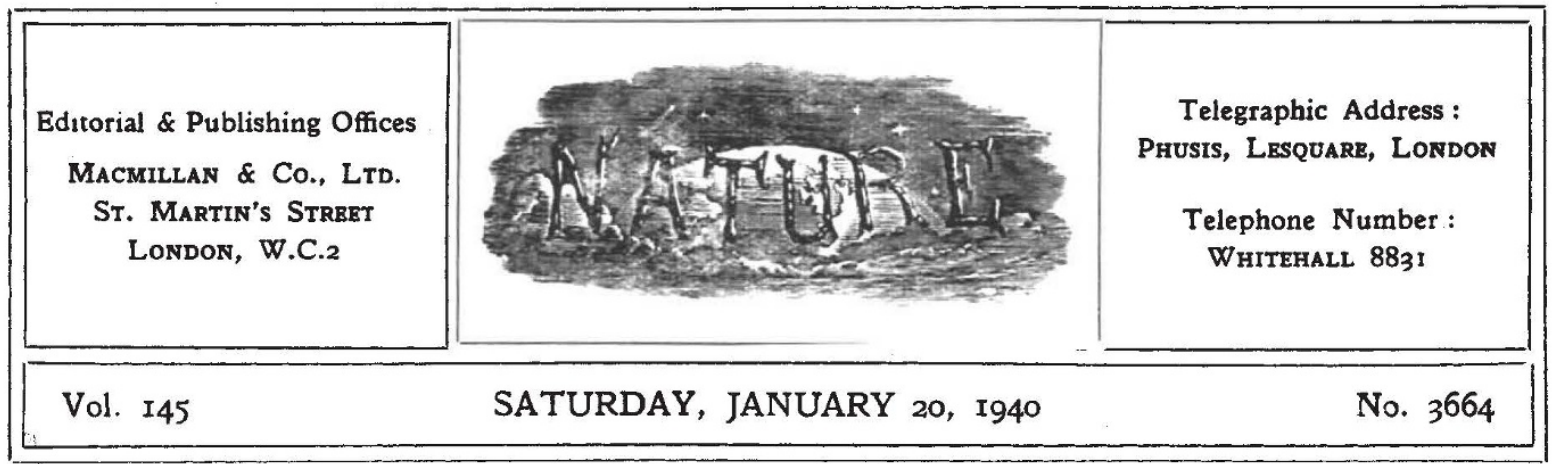

\title{
DIRECTION AND UTILIZATION OF RESEARCH
}

$I^{\mathrm{T}}$ is not always realized that, when research in the laboratory has succeeded in producing a new article or product for manufacture, it is probable that a considerable amount of capital has to be spent-not only on plant, but also on overcoming engineering and chemical difficulties, and often in creating a demand for the product -before any return can be obtained. Under modern conditions one individual can rarely take all the steps required for the development of a new product - the research work, the design and running of the small-scale plant, the market investigations, the design of the full-scale plant, the building of the factory, the running of it, the management of labour, the control of output to meet the demand, the creation of demand, the actual selling and the finding of the capital to erect the plant and for trading. Most of these steps require specialists, and it could scarcely be expected that one man should have the knowledge to do them all well ; if he had, it would be difficult for him to decide to which he should give his chief attention as the development proceeded.

Let us consider where and how research comes into the scheme of things. In the beginning, it is not usually obvious that a research reaching a successful conclusion is one suitable for development. Although a successful development may afterwards seem to have been very obvious, it was probably not so obvious at the time. There are always doubts as to the potentialities of the market, and even perhaps as to the availability of the raw materials at a cost which will leave a profit. A decision has to be made ; a risk has to be taken. Hence the question of finance enters into the problem, for those responsible for finding the capital have to be persuaded that the risk is a reasonable one. This task is an important function of the 'director of research', and without him there are sure to be difficulties, misunderstandings, and perhaps in some cases recriminations. It is a matter of experience that the research worker who makes the discovery or devises the process is rarely the best person to win the necessary confidence of an administrative board.

It is of first-rate importance, therefore, to consider the qualifications of a successful director of research. First of all, he must be himself a scientific worker. He must understand the research workers' outlook; he must encourage their enthusiasms. On the other hand, he must have a keen appreciation of developments on which the administrative body is prepared to spend money. He must know as much as he can of all branches of the industry from manufacture to sales, or he will never be able to understand the outlook of the administrative board. His knowledge of science should enable him to have a broad idea of the lines on which the industry may be expected to develop, and he should continually keep the board and departmental managers informed of the lines on which he expects development to be made.

Although the director of research will not find much time for doing research himself, he must not allow administration to become his chief interest. $\mathrm{He}$ must believe in the scientific method of approach to a subject; he must be continually assisting in summarizing and relating the results of incompleted researches, and to do this he must have been a successful research worker himself. $\mathrm{He}$ should be a helpful critic of the researches of his staff. 
While it may be conceded that an able director of research is needed in a commercial company to obtain the confidence of the administrative body for the development of scientific discoveries, it is not generally appreciated that directors of research of Government departments and research associa. tions have similar tasks. There are now a considerable number of directors of research in Great Britain, and they have been an essential factor in the successes which science has achieved in industry and in the arts of peace and war. But the functions of these men are not generally understood by men of science, by Government departments, or by politicians, though these services are realized by many industrialists. Their services to science itself are rarely recognized, although some of them have been elected to the fellowship of the Royal Society before they became directors of research. It is generally impossible for the successful director of research to devote himself sufficiently to one subject, and in consequence this acknowledgment from the world of science rarely comes his way.

At the present time, when ministries and Government departments are being subjected to frequent scrutiny, it is opportune to recommend to them the inclusion of a director of research in their organizations. Some of the ministries have them, and probably would not be without them now. Others have scientific advisers who give advice when asked, but this is not what is required. Every ministry should have, as an integral part of its personnel, a director of research, in close touch with all its problems, whose principal duty would be to advise the ministry when the man of science can be helpful. The director of research would not, as a rule, attempt to give the scientific advice himself, but a small organization under his control would see that it was obtained from the best sources available, and, as further research would be needed in most cases, he would arrange for it to be done. The Ministry of Food should certainly have a director of research, and the Ministry of Agriculture too; he would enable these ministries to make fuller use of the Agricultural Research Council, and the Medical Research Council, as well as other research workers. Another department which might well have a direetor of research is the Board of Trade, to enable the Board to make use of the potentialities of the Department of Scientific and Industrial Research. Appointments such as these would add relatively little to the budgets of the departments concerned, but would go a long way towards ensuring efficiency in the utilization of the scientific resources of Great Britain.

\section{DESIGN IN NATIONAL LIFE}

The Shape of Things

An Introduction to Design in Everyday Life. By Noel Carrington. Pp. xv +209 . (London: Ivor Nicholson and Watson, Ltd., 1939.) $6 s$. net.

\footnotetext{
A SUGGESTIVE chapter in Bavink's "Anatomy of Modern Science" is devoted to a discussion of the technological ideal of fitness for a purpose. Over an increasingly wide sphere of life we are becoming aware to-day that the squalor, ugliness and lack of beauty in our surroundings are due at least in part to the neglect of this principle. The deplorable position of the Special Areas can be directly attributed, as the successive reports of the commissioners for those areas show, to our lack of design in the planning of industry. The acuteness of the problems in the government of London can be traced to a like cause, and chaos in transport, ribbon building and the destruction of amenities have a similar origin in the absence of any comprehensive design
}

sufficient to compel planning and control on an adequate scale.

It is not only in such matters that we have failed to utilize the possibilities which new materials and new means, put at our disposal by science, have afforded. In the smallest things of everyday life, the use of such materials or forces is apt to be determined less by their intrinsic qualities than by the traditional forms in which the materials they are superseding or displacing have found expression. Outstanding examples are to be found in the tardiness with which the motor-car has freed itself from forms imposed by the tradition of the horse-drawn vehicle, and the resistance of the building industry to the adoption of new forms and possibilities inherent in the steel framework or the new plastics.

Resistance or delay of this type is, however, not due entirely to the conservatism of the manufacturer. It is also partly due to the absence of a public awake to the possibilities and sufficiently 